\title{
Clubes carnavalescos negros na cidade de Pelotas
}

\author{
Beatriz Ana Loner* \\ Lorena Almeida Gill**
}

Resumo: $O$ artigo trata da organização negra na cidade de Pelotas, particularmente com relação aos seus clubes carnavalescos, que tiveram seu auge entre os anos de 1920 e 1950. Pretende-se descrever os principais clubes e sua evolução, analisando seu papel e sua importância para a comunidade negra pelotense.

Abstract: The present paper refers to Afro-Brazilian organization in the city of Pelotas, particularly the Afro-Brazilian carnival's clubs between the 1920's and 1950's. We intend to describe the most important clubs and their evolution, analyzing their role and importance for Pelotas' Afro-Brazilian community.

Palavras-chave: Organização negra. Carnaval. Negros.

Key words: Afro-Brazilian organization. Carnival. African descendents.

Neste artigo pretende-se discutir a organização negra em Pelotas, com ênfase na formação dos clubes carnavalescos negros da cidade. ${ }^{1} \mathrm{Em}$ outros trabalhos (Loner, 1999a e 2001), já se descreveu a trajetória dos negros pelotenses até a primeira metade do século XX, em sua busca, contraditória, mas efetiva, pela inserção e participação na sociedade brasileira. Aqui, apenas se trará os dados essenciais para que se possa entender como se deu a transformação organizativa e identitária deste grupo, que passou de uma extensa rede organizativa própria, iniciada ainda no período imperial, para uma associatividade reduzida apenas

* Professora da Universidade Federal de Pelotas. Doutora em Sociologia pela UFRGS.

** Professora da Universidade Federal de Pelotas. Doutora em História pela PUCRS.

$1 \mathrm{O}$ artigo é resultado de uma pesquisa financiada pelo $\mathrm{CNPq}$, e que contou com as bolsistas e voluntárias Débora Clasen de Paula; Marcele dos Santos, Viviani Tavares e Fernanda Oliveira da Silva.

Estudos Ibero-Americanos, Porto Alegre, v. 35, n. 1, p. 145-162, jan./jun. 2009 
às entidades recreativas e esportivas, na década de 1940 e seguintes, em parte consolidando exatamente o estereótipo que pesava sobre os negros no Brasil.

Trazido como escravo para esta região, o grupo negro tendeu, para o final do período imperial, a congregar-se em entidades mutualistas, profissionais ou étnicas, que ainda não buscavam a construção de uma identidade racial, mas sim auxiliar na inclusão social e amparar seus sócios. Com a República, suas entidades evoluíram para a formação de uma rede associativa praticamente completa, surgindo propostas identitárias entre este grupo, embora sofresse com a influência desagregadora de ideologias, como a do branqueamento, com forte apelo na sociedade brasileira.

A inserção produtiva e social do negro no Brasil apresentou diferenciações regionais, influenciadas pela oferta de trabalho e pelas correntes migratórias. Dessa forma, enquanto em São Paulo o negro foi praticamente excluído do mercado de trabalho (Andrewa 1998), para outros estados, como o Rio de Janeiro (Cruz, 2000) e a Bahia (Castellucci, 2004), este formou parte considerável da força de trabalho urbana. Quanto ao Rio Grande do Sul, os negros estiveram presentes desde seu povoamento como trabalhadores escravizados trazidos para os campos e cidades. Especialmente na região sul, devido às charqueadas (Cardoso, 1962), foi grande a utilização do negro, que, após a abolição ali continuou residindo, integrando-se como trabalhador manual ao mercado de trabalho da região.

No Rio Grande do Sul, apenas recentemente se buscou desvendar os caminhos do negro durante a República. Para Porto Alegre, contamos com os estudos de Müller sobre as entidades negras (1999), enquanto Barcellos (1996) estudou a forma de estruturação familiar da classe média negra, e Germano (1999) preocupou-se em analisar as formas de carnaval negro nesta cidade. Na Antropologia, há várias pesquisas sobre sociabilidade urbana e religião, de que são exemplos os trabalhos organizados por Leite (1996) e Oro (1994). Para o interior do estado, temos os estudos de Loner (1999b) referente à organização negra e operária em Pelotas, e se começa a buscar pela população afrodescendente mesmo em regiões de colonização estrangeira (Gomes, 2007). Outra vertente de pesquisa recente, em uma parceria da História com a Antropologia, é aquela que procura confirmar as terras de origem quilombola.

Pelotas, cidade que enriqueceu com os produtos da charqueada, teve uma expressiva presença negra em seu povoamento, pois eles formavam 
um terço da população urbana em 1890. Contudo, se consolidou na cidade uma ideologia conservadora e elitista (Loner, 2001), fazendo com que a discriminação racial, após o final da escravidão, fosse muito forte, como pode ser observado pelos relatos de antigos moradores ou cronistas negros. Em algumas de suas praças, negros não podiam sentar, assim como não tinham ingresso em cafés, cinemas, teatros e outros estabelecimentos públicos. Em 1927, as principais associações negras vieram a público denunciar esta e outras formas de discriminação vigentes na cidade. ${ }^{2}$

Como forma de reação, os negros pelotenses formaram uma completa rede associativa, que incluía clubes recreativos, teatrais, carnavalescos, futebolísticos (clubes e federação de futebol) entidades mutualistas, de assistência às crianças e de representação, as quais auxiliavam na integração de seus membros na sociedade, em termos de construção de relacionamentos, amizades, relações de compadrio e, obviamente, de oportunidades de emprego e casamento. A rede associativa começou a se desenvolver ainda no período escravista, se consolidando e diversificando nas primeiras décadas da República. Entretanto, por volta de 1915-1920, evoluindo mais rapidamente nas duas décadas seguintes, houve uma reorientação das entidades, que abandonaram seu caráter de representação, o mutualismo e os objetivos educacionais, para dedicarem-se principalmente às questões de sociabilidade e recreação. Datam dessa época a criação das primeiras entidades dedicadas especificamente ao futebol, e a ênfase dada às associações carnavalescas, com o nascimento dos clubes que, meio século depois, iriam se tornar os únicos representantes do associativismo negro na cidade.

\section{Organização inicial}

No tempo do Império, as primeiras sociedades que apresentavam forte ou exclusiva presença de negros e mestiços eram suas associações mutualistas, seja de categorias (como, por exemplo, a Fraternidade Artística, de artesãos negros), ou do grupo como um todo (caso da Feliz Esperança, que aceitava inclusive sócios escravos). Estas e outras foram criadas por volta da década de 1880 , momento que se constituiu também no início da campanha abolicionista na cidade. Havia, ainda, a Irmandade da Santíssima Virgem do Rosário, entidade católica criada anteriormente. 
Os negros, contudo, também eram encontrados em entidades mistas, especialmente naquelas que diziam respeito à organização profissional, como a Harmonia dos Artistas, cujo primeiro presidente era de "tez escura", como referenciado pelos jornais da época. Já as entidades recreativas eram normalmente separadas, seja pelas nacionalidades, seja por categorias, e, ainda, pela cor da pele, já que existia o Recreio dos Artistas, para as famílias de artesãos brancos e o Recreio dos Operários, freqüentado pelos de maior pigmentação. Mesmo para aquela década recuada, existia certa diversidade associativa, pois se encontrou um Grêmio Dramático vinculado ao Recreio dos Operários, e pelo menos uma entidade carnavalesca, os Netos d'África, de presença marcante na "festa da emancipação dos escravos", de 1884.

$\mathrm{Na}$ República, esta rede associativa se diversificou e multiplicou, visando a preencher todas as necessidades de sociabilidade e cultura da comunidade, havendo associações variadas entre eles, embora seja difícil relacionar estas primeiras entidades a diferenciações internas ao grupo, em parte pelas escassas fontes encontradas. Contudo, havia a forte presença de um setor, entre a massa de afro-descendentes da cidade, formado por aqueles que buscavam a integração na sociedade como trabalhadores manuais, militares ou empregados públicos e que eram a maioria dos sócios e diretores das associações negras na cidade. Muitos deles também eram encontrados nas diretorias e nos conselhos de entidades profissionais de operários. Esses grupos funcionavam como liderança de classe e de raça ${ }^{3}$ para os negros, e são deles as principais ações no sentido da melhoria das suas condições de vida, como, por exemplo, através da promoção de cursos de primeiras letras para associados e seus filhos (imprescindíveis num momento em que muitas crianças negras eram praticamente proibidas de freqüentar a escola ou humilhadas em sala de aula, quando aceitas). De outra parte, através da luta sindical, tentavam conseguir melhores condições de trabalho para os operários, entre os quais, na região, muitos eram os afro-descendentes (Loner, 1999b).

3 Há certo tempo abandonou-se o estudo de raças humanas no sentido biológico, o que não ocorre em termos antropológicos ou sociais, em que, devido às complexas mediações da construção de identidades culturais e coletivas, ainda se discute a validade do termo raça, especialmente em relação aos negros. Nesse artigo não pretendemos discutir esta questão, remetendo os leitores interessados a Hofbauer (2006), o qual mapeia a questão, ou, na compreensão da existência de uma raça social, a Guimarães (2002). 
Essas lideranças perseguiam um processo de ascensão coletiva do grupo negro, o que incluía educação e organização na luta contra a marginalização, que lhes era reservada pela sociedade republicana, especialmente em cidades conservadoras e com hábitos aristocráticos, como era Pelotas. O jornal A Alvorada, que teve uma longa atuação entre a comunidade negra e operária da cidade, fundado em 1907 e existindo até meados da década de 1960, compartilhava deste projeto, pois uma parte da direção do jornal e de seus colaboradores compunha-se de militantes operários, que Santos (2003) chama de intelectuais negros, pois tinham uma proposta de integração na classe operária.

No ano de 1933, houve a mais importante iniciativa de organização política negra na cidade, com a formação da Frente Negra Pelotense, que se propunha a lutar pela educação e elevação do negro na sociedade, articulando um expressivo grupo, na tentativa de conscientizar os demais, através de palestras e conferências nas associações negras. A Frente Negra Pelotense enviou um representante ao $1^{\circ}$ Congresso Afro-brasileiro do Recife (1934), o qual leu um manifesto denunciando a existência da segregação no sul. Apenas em poucas cidades do país houve a criação de associações do mesmo gênero, a maioria delas, tal como a pelotense, inspirada na Frente Negra Brasileira de São Paulo, que depois progrediu para a idéia da criação de um partido negro, o que não aconteceu devido à conjuntura repressiva do Estado Novo (Andrews, 1998). Contudo, a Frente Pelotense era diferenciada ideologicamente, pois, além de lutar contra a discriminação racial, buscava, através da educação, capacitar o grupo negro a ocupar uma melhor posição na sociedade e tinha elementos socialistas em seu seio, enquanto a frente paulista era simpática ao governo Vargas e desenvolveu posturas xenófobas.

A Frente Pelotense enfrentou várias incompreensões, inclusive da própria comunidade, mas manteve-se em atividade de 1933 a 1936 , constituindo-se num momento determinante de politização da luta do negro na cidade. Em 1934, surgiu o Partido Socialista Proletário Brasileiro, que concorreu às eleições daquele ano com oito candidatos em todo o estado, quatro deles militantes da Frente Negra Pelotense.

No episódio da formação da Frente Negra, pode-se observar a diferenciação interna da comunidade, pois havia muitos que, negando as raízes africanas e afastando-se dos demais, trilhando caminhos individuais de ascensão e integração na sociedade, consideravam não haver motivo para a sustentação dessa Frente. A polêmica pode ser acompanhada através das páginas dos jornais, especialmente do A Alvorada. A própria 
conjuntura encarregou-se de definir a questão, pois com o fechamento político da segunda metade da década de 30, culminando na ditadura do Estado Novo, as vozes operárias e socialistas tiveram de se calar e as associações de que participavam foram eliminadas, apenas subsistindo as entidades recreativas e esportivas, entre as quais estavam os clubes carnavalescos que são objeto expresso deste artigo.

A ideologia do branqueamento disseminou a idéia de que, com o tempo, o negro terminaria sendo absorvido pelo elemento dominante branco e, portanto, não se necessitaria ter políticas de Estado para sua integração, pois tenderia ao desaparecimento, ao cabo de algumas gerações. Mas há um outro viés dessa ideologia, que incide mais fortemente sobre a subjetividade individual, fazendo dos elementos do próprio grupo dominado, cúmplices de sua dominação. Hofbauer entende que a idéia do branqueamento esteve presente desde os tempos coloniais, com "o ideal do branco sendo (re)semantizado constantemente". Para ele,

o ideário do branqueamento postula a supremacia do branco e, ao mesmo tempo, induz os indivíduos a se aproximarem deste ideal. Traz em si um potencial de resistência contra qualquer tentativa de essencializar os limites de cor e ou de raça, uma vez que faz com que os indivíduos tendam a apostar em negociações pessoais e contextuais das fronteiras identitárias e tendam a rejeitar processos e mecanismos formais de delimitá-las. Essa prática social tem contribuído para encobrir o teor discriminatório embutido nesse esquema ideológico e também para abafar eventuais contra-reações coletivas (Hofbauer, 2006, p.27-28).

Dessa forma, muitos negros recusaram considerar a possibilidade da existência do racismo, vendo a sociedade pelos próprios olhos dos grupos dominantes e assimilando seus valores e padrões de comportamentos. Por exemplo, em 1942, ao justificar porque considerava que o Fica A $i$ não deveria participar de um "festival patriótico", o qual culminaria numa apoteose das três raças formadoras do Brasil, como parte do esforço de guerra, seu secretário afirmou que, conhecendo o organizador do espetáculo, sabia que os negros seriam apresentados

com suas representações africanas [colocando] as pessoas que têm a mesma cor de sua pele, em uma flagrante demonstração de inferioridade perante as pessoas imbuídas na confraternização racial brasileira, que desconhecem preconceito de cor, que reconhecem somente o nível intelectual e moral dos homens. Por isso acha inconveniente que o Fica Ai coopere nessa demonstração de solidariedade, ou melhor, de inferioridade, ao sr. Presidente da República (Ata 248, de 30/9/1942). 
Domingues (2004) estudou os efeitos desse tipo de comportamento para São Paulo, desvelando resultados parecidos com aqueles aqui assinalados. Sansone (2003), em trabalho de pesquisa sobre bairros negros na Bahia atual, chega a resultados muito ilustrativos do quanto, até hoje, a noção de cor e raça continua a ser móvel no Brasil.

\section{Os clubes carnavalescos}

O carnaval em Pelotas era modelado por aquele do centro do país (Queiroz, 1992; von Simson, 1989), entretanto, era o mais forte do interior, especialmente quanto ao carnaval de rua, e mantinha um forte apelo entre a população local. No início da República, o carnaval de Pelotas concentrava-se ao redor de bailes à fantasia, em salões ou em casas, passeios burlescos, corso com carruagens, além do persistente entrudo, que se buscava coibir. Nas primeiras décadas do século XX, surgiram novos clubes de classe média ou alta, e passou-se ao carnaval de rua, com a participação de blocos e cordões e desfiles de carros (Barreto, 1996). Durante os anos 20 e 30, houve muitos desfiles de rua dos cordões e blocos existentes, entre eles, aqueles que reuniam os negros.

Queiroz (1992) e von Simson (1989) demonstraram que, para o Rio de Janeiro e São Paulo, o carnaval da elite ocorria em espaços completamente separados daquele do carnaval popular. Entretanto, em Pelotas, todos os clubes se apresentavam nos mesmos locais, em algumas ruas centrais e no entorno da atual praça Cel. Pedro Osório, bem no centro da cidade. Contudo, os dias eram separados, pois os clubes de classe média e alta, como o Diamantinos e o Brilhante, se apresentavam em um dia e os cordões em outro. Havia mais, pois as classes/grupos da população costumavam ocupar locais diferentes nos lados da praça. Dona Sirlei ${ }^{4}$ revela que a concentração de jovens na Praça Coronel Pedro Osório era muito grande. "Do [clube] Caixeral até a esquina do [banco] Itaú parava a classe rica branca [...] e a classe mais pobre negra ficava da esquina do Itaú até a Prefeitura”.

Para as primeiras décadas republicanas, as principais associações recreativas que aceitavam negros eram o Recreio dos Operários, que teve depois uma dissidência, a S. B. Satélites do Progresso, em 1891, e o clube carnavalesco Flores do Paraíso, em 1898, a S. R. Quadro

4 Depoimento de Sirlei da Silva Amaro, obtido no dia 22 de agosto de 2003. Acervo do NDH/UFPel. 
da Aliança, de 1902 e um pouco mais tarde, o Grêmio Recreativo 24 de Junho, que existiu pelo menos até $1929.5^{5}$ Várias outras entidades surgiram, algumas durando apenas um ou dois carnavais, outras com maior duração. Em meados da década de 10, começou o processo de desaparecimento de entidades tradicionais, como a Feliz Esperança, Satélites do Progresso e Recreio dos Operários, e o surgimento de blocos e cordões carnavalescos, ao mesmo tempo em que os clubes de futebol negros se organizavam e formavam uma Federação, a Liga José do Patrocínio (1919).

O primeiro desses clubes carnavalescos de nova geração, o Depois da Chuva, nasceu em 1917, e já em 1929 estava inaugurando sua sede própria, em zona central da cidade. Esse clube manteve atividades até meados da década de 80 , estando atualmente seu patrimônio invadido por um posseiro urbano e tendo desaparecido seus principais documentos. Foi inicialmente apelidado de clube dos "cisqueiros", pois era próximo a um depósito de lixo da prefeitura. Posteriormente, com a maior urbanização do local, passou a ser o clube da zona da "Cerquinha", sendo que, nas décadas de 1940 e 1950, vários blocos carnavalescos se originaram dessa região, como o "Girafa da Cerquinha".

O Quem Ri de nós tem paixão, nascido em 1921, sobreviveu até inícios de 1940. Apesar de ser um clube muito popular, prestigiado pelos seus desfiles na rua, estando bem colocado em concurso do "cordão carnavalesco mais simpático" (Folha do Povo, carnaval de 1938), ele desapareceu completamente da memória das pessoas da cidade, sendo que, de todos os depoentes, apenas uma pessoa declarou saber que um parente fora ex-sócio deste clube. Sua sede era na rua Urbano Garcia, em direção ao Areal, então uma zona de moradia de trabalhadores. Ele parece muito vinculado ao G. R. 24 de Junho, em cuja sede fazia a maior parte de suas festas.

Já o Chove não molha foi fundado no dia 26 de fevereiro de 1919, na alfaiataria de Otacílio Borges Pereira, por um grupo que resolveu, segundo sua ata de fundação ${ }^{6}$, organizar um grupo apenas para festejar o carnaval de 1919. Como a integração foi grande, resolveram criar o Grupo Carnavalesco Chove não Molha, o qual ainda está em atividade, com sede própria. Em 1938, em concurso realizado pelo

5 O quadro total das entidades negras da cidade, para a República Velha, bem como as referências que embasam esta pesquisa, já foi apresentado em Loner, 1999a.

6 Documento oficial do Clube, existente em seu arquivo. No documento é dito que no ano de 1966, houve seu reconhecimento como de utilidade pública, passando a denominar-se Clube Cultural Chove Não Molha. 
jornal Folha do Povo, ele foi eleito como o cordão carnavalesco mais simpático. ${ }^{7}$

Quanto ao Está tudo certo, só surgiu em 1931, e teve importante participação até a década seguinte nos carnavais de rua, sendo o principal clube de jovens negros da década de 1930. Sua vida está ligada ao jornal A Alvorada e ao Dr. Juvenal Penny, que foi seu diretor e também era dono do jornal nesse período. Sua sede era bem central, na rua General Osório.

O Clube Fica Ai para ir Dizendo foi fundado em 27 de janeiro de 1921, como um cordão carnavalesco, com o objetivo de congregar pessoas para brincar o carnaval. Seu primeiro ponto de encontro foi a Praça Coronel Pedro Osório, no centro da cidade. Há várias versões sobre sua fundação e seu pitoresco nome, uma delas informando que seria uma dissidência do Chove Não Molha, provocada por desentendimentos iniciados em jogo de futebol entre os clubes América e Juvenil, a qual evoluiu para separação de parte dos sócios, que foram fundar o Fica $A i^{8}$ e um deles permaneceu no local, para avisar aos demais. Conseguiu construir edifício próprio na década de 1950, estando em atividade até hoje. Seus sócios eram, dentro da comunidade, o que se poderia chamar de elite negra, famílias com uma situação social mais estabelecida, os quais poderiam arcar com as despesas necessárias para freqüentar o clube e que atingiam as elevadas exigências associativas do mesmo.

Houve outras sociedades, um deles o S. R. Democráticos, aparecido em 1934, sobre o qual os depoimentos orais ${ }^{9}$ informam que seria de mulatos, e discriminaria pessoas de cor mais escura. $\mathrm{O}$ último clube negro dessa década foi o Juvenil. Em 1937, surgiu o Bloco carnavalesco Futurista, que procurou limitar suas atividades ao carnaval de salão, exigindo muito luxo em suas vestimentas, mas tendo um comportamento muito aberto em relação aos participantes de seus bailes.

Entretanto, mesmo tendo por objeto principal apenas o carnaval ou o esporte, o que configura uma involução em relação à extensiva rede associativa anterior, estes clubes representavam a população negra da cidade. De fato, em 1927, eles formaram as principais entidades que

7 Chama a atenção neste concurso que, dos seis cordões mais votados, os primeiros cinco eram negros.

8 Informação oral prestada pelo senhor Mario Chagas, atual presidente do Chove não Molha, em 31/08/2007.

9 Entrevista de José Facundo Mira, em 10 de julho de 1996, em Pelotas, a Beatriz Loner. Além deste, outros depoentes reportaram também haver um clube que promovia a discriminação com base na cor. 
denunciaram a existência de racismo na cidade, aos que se somaram os esportivos. E, de 1933 a 1935, era também nestes clubes que se realizavam as sessões e conferências da Frente Negra Pelotense, embora alguns fossem mais receptivos às suas propostas do que outros. Mais particularmente sensível aos apelos da Frente pareciam ser os dirigentes do Chove, que abriam amplo espaço para suas atividades, como aulas e palestras, além de propiciar auxílio nas tarefas de arrecadação financeira (A Alvorada, 2/9/1934 e 30/9/1934). Também o Está tudo Certo, composto de jovens, contribuiu com a Frente, inclusive com militantes em conjunto.

Embora seja difícil medir o grau de politização de clubes cujo objetivo básico fosse o lazer e que, mais do que tudo, percorreram uma longa trajetória, portanto, passando por muitas conjunturas diferenciadas, algumas atitudes devem ser destacadas, pois uma posterior e mais aprofundada pesquisa pode elucidar em que medida representariam diferenças entre os sócios de cada agremiação. Assim, o Depois da Chuva parece ser o mais politizado, fazendo uma passeata comemorativa à revolução de 1930, em 15 de novembro do mesmo ano, e, logo a seguir, uma coleta de dinheiro para resgate da dívida do Brasil (A Opinião Pública, 13/11/1930). Mas em fevereiro de 1932, eles saíram às ruas com uma faixa com os dizeres "Salve a Constituinte", o que, sabe-se, não era propriamente a expectativa de Vargas. Havia um bom intercâmbio entre o movimento sindical e os clubes, pois representantes do Depois da Chuva participaram de cerimônias no Sindicato dos Marítimos, e a Frente Sindicalista Pelotense realizava assembléias em sua sede em 1934. Também o Chove algumas vezes emprestou sua sede para reuniões dos sindicatos dos alfaiates e dos chauffeurs. Obviamente, conforme a situação do país se tornava mais tensa, ocorrendo o fechamento político, essas atitudes desapareceram, substituídas por cerimônias de entronização do retrato do Getúlio, ou participação no esforço de guerra.

Vinculados a esses clubes ou às agremiações esportivas, surgiram vários outros grupos ou blocos carnavalescos que funcionavam dentro deles, agregando sócios, e que se apresentavam, nas festas, desfiles e outras atividades internas, como agremiações próprias. ${ }^{10}$ Costumavam organizar promoções, especialmente bailes para auxiliar os clubes e, em sua fundação e organização, as mulheres tinham uma forte importância.

${ }^{10}$ O Bloco das Sevilhanas pertencia ao Chove, antes de se autonomizar, e o Bloco dos Futuristas só existiu dentro deste clube. 
Com relação à participação feminina, os clubes negros mais tradicionais apresentavam especial preocupação. Assim, ao mesmo tempo em que possuíam uma diretoria feminina sempre presente e atuante, os homens exerciam grande vigilância sobre o comportamento das sócias, inclusive desligando filiadas que não seguiam os padrões restritos da moralidade vigente na época, enquanto o comportamento masculino era vigiado apenas em relação a bebedeiras ou brigas no recinto social, para evitar desordens e tumultos. Para conter esses problemas, os principais clubes fizeram uma reunião, ainda em 1932 (A Alvorada, 14/8/1932) em que foram definidas formas de controle comum dos elementos desordeiros e, mais tarde, o Fica Ai, pelo menos, terminou com a prática dos convites para os bailes, reservando suas promoções exclusivamente para associados. Isso, se resolvia parte do problema, refletia-se na sustentação financeira dos clubes, que ficavam na dependência exclusiva dos sócios e do pagamento das mensalidades, além de módica contribuição da prefeitura para o carnaval ou do dinheiro arrecadado em festivais, prática corrente da época. Porém, da mesma forma que outras agremiações, como o Bloco dos Futuristas e o Bloco das Sevilhanas, utilizavam a prática da venda do convite, desenvolveuse certo preconceito quanto a seus bailes, por parte do Fica Ai, que tentava inibir a participação de seus associados nestas festas, punindo as sócias que os freqüentassem.

Isso nos remete também a outra preocupação constante desses clubes, referentes à forma de sua integração na sociedade pelotense. O Fica Aí utilizava, como padrão de comportamento para seus sócios, o mesmo vigente nos clubes de classe média da cidade, sendo extremamente rigoroso com a moral e o vestuário próprio para festas, etc. Os demais, aparentemente, eram mais flexíveis neste último ponto, compreendendo a dificuldade de seus associados, vários deles trabalhadores de serviços ou comércio da cidade. Contudo, no conjunto, sua inserção social era limitada, pois pelo menos até a década de 1950 , não há notícias de convites ou intercâmbios com os clubes brancos da cidade, havendo apenas algumas ações comuns, tomadas no foro do Comitê Carnavalesco, em relação à questão dos desfiles.

A evolução do carnaval de rua em Pelotas levou a que, no início dos anos 30, os cordões carnavalescos negros dominassem a cena. Havia dias marcados para seus desfiles e seu corso, e eles eram aguardados com muita expectativa pelo público, sempre caracterizado em vários milhares pelos jornais. Pelotas possuía o principal carnaval do interior do estado, e isso resultava em afluência de estrangeiros, como os cerca 
de mil uruguaios que viriam assistir aos desfiles em 1939 (Folha do Povo, 22/12/1938).

Contudo, naquele final de década, o carnaval de rua entrou em séria crise. Em 1937, em protesto contra decisão da Câmara Municipal, que disponibilizou uma verba muito baixa para os desfiles, cinco cordões negros, mais o Es..pia Só, comprometeram-se, em reunião conjunta, a não desfilar (Diário Popular, 5/1/1937). Coincidentemente ou não, os jornais informaram, neste ano, sobre a intenção de alguns clubes brancos, de "reviver" o carnaval de rua de Pelotas. E efetivamente, eles fizeram desfiles naquele carnaval, mas, segundo a insuspeita fonte do principal jornal de Pelotas, sem conseguir substituir os cordões, pois, "faltou às ruas a sua alma popular... Conquanto Diamantinos $e$ Fantoches tivessem preenchido um espaço de alegria carnavalesca, ficou, entretanto, um vácuo que era preenchido pelos nossos briosos cordões" (Diário Popular, 16/1/1937).

Naquele final de década, armou-se uma conjuntura extremamente complicada para a manutenção dos corsos de rua. A partir de 1938, com a decretação do Estado Novo, impuseram-se regras especiais, tanto para desfiles nas ruas, quanto para simples reuniões associativas e recreativas, que passaram a necessitar da permissão da polícia. Em 1938 e 1939, alguns dos cordões saíram às ruas, mas o problema com a falta de financiamento continuou, agravado pela cobrança de taxas e impostos estaduais, os quais oneravam o desfile, fato criticado pelo Folha do Povo (23/01/1940), que entendia que cordões compostos por trabalhadores não poderiam ser onerados. Mesmo com a suspensão dos tributos, o brilho dos desfiles não voltou ao patamar anterior para os cordões. Por outro lado, a Prefeitura afirmava que liberara verbas, embora haja uma significativa diferença no montante para os cordões estudados, neste ano, e o Diamantinos e Fantoches, que desfilaram nas ruas em 1939 e 1940 . Não fica claro o motivo, embora tudo leve a crer que a diferença se devesse ao fato de estes últimos terem desfilado nas ruas e os demais não (A Opinião Pública, 23/01/1940).

Outro motivo da desistência das sociedades negras pelo desfile nas ruas talvez esteja relacionado ao incidente acontecido no desfile do Chove em 1939. A descrição do jornal é por demais significativa e, devido a isso, apesar de longa, vamos transcrever a maior parte da notícia:

\section{Carnaval de sangue}

A sociedade culta e ordeira desta terra assistiu, ontem, em pleno carnaval, a um fato inédito nos anais de sua história sem mancha: a um grupo de civis, tendo entre si pessoas de responsabilidade pelos 
cargos que exercem, com uma patrulha, a golpes de sabre [sic], o ordeiro e tradicional Cordão Carnavalesco "Chove Não Molha", que ia em passeata pela principal rua da cidade.

O querido cordão Pelotense, tradicional pela sua compostura e pela sua seriedade, transitava, debaixo de aclamações pela Rua Andrade Neves, segundo a voz unânime da população, quando um grupo de pessoas em traje civil, que as autoridades estão identificando, penetrou na formatura, tentando agarrar, em gestos obscenos, as senhorinhas que faziam parte do préstito.

Em legítima defesa de seu patrimônio moral e para resguardar, também, os foros de honradez da nossa população - que jamais assistiu cenas desse jaez - o pessoal do cordão, num revide justo, expulsou do seu seio o grupo em desordem.

Pondo-se em marcha, sob vitores e palmas, o simpático conjunto entrou, sempre sob aplausos, na nossa Rua XV, a principal artéria, onde um povo inteiro - principalmente senhoras e crianças - assistia ao desfile.

Quando já em frente à Confeitaria Gaspar, perante uma multidão confiante, desenrolou-se, então a tragédia. Surge, de inopino, um grupo de soldados (não se sabe ainda por ordem de quem) e dissolve a golpes de sabre, o cordão em marcha.

Imagine-se uma batalha em plena rua 15 , onde estavam, talvez trinta mil pessoas, e ter-se-á, a idéia do que foi a hecatombe.

Mulheres feridas, crianças aos gritos, casas invadidas, cadeiras quebradas, a confusão, a dor, o sangue, enfim. Diversas pessoas, inclusive senhoras, receberam curativos na Santa Casa.

Há uma sombra de tristeza envolvendo a cidade em luto.

A imprensa, que é uma auxiliar da ordem, não pode silenciar diante desse fato inominável, que constitui uma diminuição lamentável do carnaval antigo, que foi sempre uma gloriosa tradição do povo Pelotense.

O nosso silêncio, atendendo a pedidos, seria a conivência com os perturbadores... (Folha do Povo, 22/02/1939, p. 4).

Nesse relato, estão presentes muitos elementos importantes: o assédio físico às mulheres participantes do desfile, dando razão àqueles que não queriam que sócias desfilassem nas ruas, ${ }^{11}$ a reação dos Chovianos e sua vitória. E depois, a retaliação dos ofendidos, que jogaram o exército contra o povo e o cordão, ferindo vários. Contudo,

${ }^{11}$ Quando os desfiles de rua retornaram, clubes como o Fica Ai só permitiram que homens desfilassem e, mesmo assim, com muitas restrições a isso. 
o texto jornalístico insinuou que havia pessoas importantes envolvidas ("pessoas de responsabilidade pelo cargo que exercem"), sendo pressionado para que nada noticiasse. Concluiu, colocando a lista de injuriados, com muitas mulheres feridas a sabre e cinturão, tendo uma delas desmaiado, pelas ofensas físicas. No dia seguinte, o jornal não circulou, proibido pela censura, que também interferiu nos demais órgãos de imprensa, inclusive forçando a que nem sequer pudesse ser feita uma campanha de solidariedade financeira ao clube. Pelo que se conseguiu apurar, pelos jornais e depoimentos orais, a agressão envolveu o exército e a Brigada, mas a conjuntura repressiva do Estado Novo sufocou todos os protestos.

Entende-se que foi este acontecimento o desencadeador para tirar das ruas os desfiles dos cordões negros, que já não compareceram no ano de 1940 e posteriores. Mais tarde, utilizaram como pretexto, o fato da entrada do país na guerra, mas todos os temores da comunidade negra estavam presentes no episódio: a tentativa de abuso de suas mulheres, a irritação dos "poderosos" com a reação dos homens negros e a intervenção armada para restaurar a "ordem" e recolocar os negros em seu "devido lugar". Humilhados e ofendidos, lembrados dolorosamente da posição subalterna que ocupavam naquela sociedade e atualizados em relação à falsidade das relações cordiais entre as "raças" no Brasil, não havia, para estes clubes, motivo para seus desfiles de rua e eles se refugiaram dentro de suas sedes, mantendo atividades apenas nos salões.

Seu espaço nas ruas será ocupado pelos blocos, que na maioria se utilizaram de nomes de bichos (Dromedários, Camelos, Girafa...) e, na década de 1950, pelo surgimento das escolas de samba. Tanto em um quanto em outro tipo de associação, se fizeram presentes muitos sócios dos clubes, mas o contexto era diferenciado. No final dos anos 40 e inícios da década seguinte, tentou-se, novamente, reeditar sua presença nas ruas, inicialmente com muita apreensão, com apenas homens desfilando e várias precauções. Mas a expansão do modelo de escolas de samba terminou por prevalecer e, embora algumas delas iniciassem seus passos dentro desses clubes, em pouco tempo terminaram por se estabelecer como entidades separadas.

Havia rivalidade entre os clubes, que competiam pelo título de melhor carnaval do ano, melhor desfile, e, às vezes, em torneios de pingpong. No entanto, ao lado dessas competições "oficiais", havia outras, só importantes internamente à comunidade, pelo orgulho de promover o festival mais deslumbrante, os bailes luxuosos e ter a melhor decoração, 
o que sempre era complicado para uma comunidade de baixa renda. Isso transparece muito claramente nas entrevistas orais, com relatos de casos em que um clube tentou "furtar" (aliciar) rainhas de outro, ${ }^{12}$ ou como o Fica Ai, que tomou resolução no sentido de proibir suas sócias de participarem em corais de outros clubes. Os padrões associativos muito exigentes e dispendiosos do clube Fica Ai, que praticamente impediam muitas famílias de participar do clube, terminavam provocando um ressentimento entre os demais, que se sentiam segregados pelos ficaianos. Segundo o relato de dona Sirlei, ela própria sócia do Depois da Chuva e do Chove não Molha, ${ }^{13}$ "'os freqüentadores do Fica Ai eram aquelas pessoas que tinham mais posses, a gente até nem ia... Eu não me lembro como é que era a discriminação, a seleção, porque as pessoas tinham que se associar, então conforme a profissão e as condições, não eram nem aceitos, então aquela pessoa que já sabia que não tinha condições, não ia mesmo".

$\mathrm{Na}$ verdade, embora no imaginário da cidade perpassem muitas explicações sobre quem seriam os sócios do Fica Ai (que passam pela seleção econômica e cor da pele, basicamente), nenhum deles se confirmou na pesquisa de seus livros de atas. O clube não aceitava brancos, mas as fotos dos sócios ressaltam uma gradação variada de cores, dos mais claros aos mais escuros. O critério financeiro era importante, como forma de atender às exigências de caros vestidos e do fraque masculino, mas não o único, pois a manutenção do padrão de moralidade adequada também era tão importante quanto as posses materiais. Com isso, não se quer dizer que os demais não mantivessem um padrão moral, mas que, neste clube, ele atingiu um ápice nunca visto em nenhum dos demais, com o clube tentando implantar padrões de comportamento para seus sócios e, por extensão, para a comunidade negra (Loner e Gill, 2005).

Os clubes pelotenses tinham uma forte inserção no estado, pois foram muitos os momentos em que viajaram para outras cidades, especialmente para Porto Alegre, Rio Grande e até Bagé, participando de festividades junto à comunidade negra e também recebendo visitas dos clubes de lá. Com o tempo, desenvolveram-se torneios, especialmente de ping-pong, que motivavam a ida ou vinda de caravanas de competidores juvenis.

\footnotetext{
12 Entrevista de Jaci Oliveira, Enilda Chagas e Idalina Cardoso, no dia 23 de novembro de 2004. Acervo NDH.

13 Idem.
} 
Quanto à programação dos clubes, todos eles seguiam um mesmo padrão: festas em datas comemorativas, como aniversário da instituição, Dia das Mães, Dia dos Pais, além de quermesses, chás dançantes e, é claro, muita atividade carnavalesca. Nos anos 30 e 40 tiveram muito destaque os chamados festivais, que combinavam manifestações artísticas com cerimônias, como a coroação da rainha. Havia vários festivais ao ano, sendo que aquele do carnaval poderia durar mais de um dia. Naqueles momentos, os cordões faziam desfiles pelas ruas, buscando em casa as homenageadas e levando-as até o teatro em que seria desenvolvido o espetáculo, com muita pompa. No carnaval, estes desfiles normalmente incluíam uma volta ao redor da praça Cel. Pedro Osório e a passagem na frente da sede de outras agremiações carnavalescas, brancas e negras. Nos tempos do Estado Novo, houve notícias de clubes, cumprimentando as autoridades policiais e militares em suas residências.

$\mathrm{Na}$ análise das atas, fica claro o papel das agremiações carnavalescas da comunidade negra, naquelas décadas, como locais estratégicos para o encontro de jovens e suas definições matrimoniais, pois se nota que muitos pais de família só pediam filiação enquanto tinham filhas em idade núbil, se desfiliando posteriormente. Dentro desta vertente, é mais facilmente entendível a situação das sócias jovens, que trabalhavam como empregadas domésticas e que, morando no emprego, podiam dar-se ao luxo da associação, pois terminavam despendendo boa parte dos seus proventos com vestimentas e bailes em busca de um possível parceiro para toda a vida.

Os clubes também poderiam auxiliar na busca de empregos e na maior qualificação profissional para seus sócios, com o oferecimento de vários cursos, como corte e costura, técnicos, etc. O Fica Ai contou com um time de futebol, sala de ginástica e grupos de danças e, durante algum tempo, abrigou a Escola Primária Francisco Simões, em convênio com o governo do estado, o que resultava em subsídio para sua manutenção, além de dar ênfase ao aspecto cultural do clube.

Ainda um último papel era cumprido por estas entidades e mostrouse muito importante na formação da identidade étnica: a instituição de concursos internos sobre "a mais bela negra", a "miss mulata" e outras denominações. Esses concursos, que se disseminaram por todas as cidades e clubes do país, começaram, paulatinamente, a reforçar a auto-imagem do grupo negro, visto, muitas vezes, de forma negativa na sociedade. Tais atividades diferiam da escolha já tradicional de rainhas e princesinhas, porque nestes, o critério de beleza não era o principal, 
já que as escolhidas eram normalmente filhas ou netas de dirigentes ou pessoas importantes dos clubes.

Contudo, nos concursos de beleza, o que estava em jogo era a afirmação de um novo padrão de beleza estética. O que se tentava provar era que a "raça" negra também podia ser bela e que os critérios de beleza, fundados apenas no modelo estético branco, não eram os únicos a serem seguidos. Essa foi uma inovação fundamental, e que repercutiu no comportamento posterior e na estratégia de auto-afirmação étnica dos negros. Os clubes de Pelotas, como de outras partes do país, participaram também desse processo.

\section{Referências}

ANDREWS, George. Negros e brancos em São Paulo (1888-1998). Bauru: EDUSC, 1998.

BARCELLOS, Daisy. Família e ascensão social de negros em Porto Alegre. 1996. Rio de Janeiro. Tese (Doutorado em Antropologia Social) - Universidade Federal do Rio de Janeiro/Museu Nacional, Rio de Janeiro.

BARRETO, Álvaro. O apogeu do carnaval veneziano em Pelotas (1906-1921). Cadernos do ISP, Pelotas, n. 8, p. 5-32, 1998.

CARDOSO, Fernando Henrique. Capitalismo e escravidão no Brasil Meridional. São Paulo: Difel, 1962.

CASTELLUCCI, Aldrin. Industriais e operários baianos numa conjuntura de crise (1914-1921). Salvador: FIEB, 2004.

CRUZ, Maria Cecília Velasco. Tradições negras na formação de um sindicato: sociedade de resistência dos trabalhadores em trapiche e café, Rio de Janeiro, 1905-1930. Afro-Ásia, UFBA, n. 24, p. 243-290.

DOMINGUES, Petrônio. Uma história não contada. Negro, racismo e branqueamento em São Paulo no pós abolição. São Paulo: Senac, 2004.

GERMANO, Íris. Rio Grande do Sul, Brasil e Etiópia: os negros e o carnaval de Porto Alegre nas décadas de 1930-1940. 1999. Porto Alegre. Dissertação (Mestrado em História) - Universidade Federal do Rio Grande do Sul, Porto Alegre.

GOMES, Fabrício. Associativismo negro em Caxias do Sul. Anais do $3^{\circ}$ Encontro Escravidão e Liberdade no Brasil Meridional, Florianópolis, 2007. www.labestc.ufsc.iiiencontro.htm

GUIMARÃES, Antonio. Classes, raça e democracia. São Paulo: Ed. 34, 2002.

HOFBAUER, Andréas. Uma história de branqueamento ou o negro em questão. São Paulo: ED. UNESP, 2006.

LEITE, Ilka B. (Org.). Negros no sul do Brasil. Invisibilidade e territorialidade. Florianópolis: Letras Contemporâneas, 1996. p. 13-32. 
LONER, Beatriz. Negros: organização e luta em Pelotas. História em Revista, v. 5, p. 7-27, dez. 1999b.

LONER, Beatriz. Classe operária: mobilização e organização em Pelotas: 18881937. 1999a. Porto Alegre. 2 v. Tese (Doutorado Sociologia) - Universidade Federal do Rio Grande do Sul, Porto Alegre.

LONER, Beatriz. Construção de classe: operários de Pelotas e Rio Grande (1888-1930). Pelotas: EdUFPEL, 2001.

LONER, B.; GILL, L. Classe, etnia e moralidade: estudo de clubes negros. In: www.anpuh.uepg.br/xxiii-simposio/anais/anais.htm. XXIII Simpósio Nacional de História - Londrina, 2005.

MÜLLER, Liane. As contas do meu rosário são balas de artilharia. 1999. Porto Alegre. Dissertação (Mestrado em História) - Pontifícia Universidade Católica do Rio Grande do Sul, Porto Alegre.

OLIVEN, Ruben. A invisibilidade social e simbólica do negro no Rio Grande do Sul. In: LEITE, Ilka B. (Org.). Negros no sul do Brasil. Invisibilidade e territorialidade. Florianópolis: Letras Contemporâneas, 1996. p. 13-32.

ORO, Ari Pedro (Org.). As religiões afro-brasileiras do Rio Grande do Sul. Porto Alegre: UFRGS, 1994.

QUEIROZ, Maria Isaura. Carnaval brasileiro: o vivido e o mito. São Paulo: Brasiliense, 1992.

SANTOS, José Antonio. Raiou a alvorada: intelectuais negros e imprensa, Pelotas (1907-1957). Pelotas: EdUFPel, 2003.

SANSONE, Lívio. Negritude sem etnicidade: o local e o global nas relações raciais e na produção cultural negra do Brasil. Salvador: Edufba/Pallas, 2003. VON SIMSON, Olga. Brancos e negros no carnaval popular paulistano (19141989). 1989. São Paulo. Tese (Doutorado em História) - Universidade de São Paulo, São Paulo.

\section{Entrevistas}

- Sirlei da Silva Amaro, no dia 22 de agosto de 2003. Acervo do NDH/ UFPel.

- Flávio Alves da Costa Farias, no dia 16 de junho de 2004. Acervo do NDH/ UFPel.

- Jaci Oliveira, Enilda Chagas e Idalina Cardoso, no dia 23 de novembro de 2004. Acervo do NDH/UFPel.

- José Facundo Mira, no dia 10 de julho de 1996. Acervo do NDH/UFPel.

\section{Outras Fontes}

- Livro de Atas de Diretoria e de Assembléia do Clube Fica Aí, referentes aos anos de 1938-1943. Arquivo do Clube.

- Livro de atas do Clube Chove Não Molha. 1931-1941. Acervo do Clube. 